\title{
Effect of hail protecting nets on the quality of apples
}

\author{
Gonda, I. ${ }^{1}$, Vaszily, B. ${ }^{1}$, Bartha, A. ${ }^{1}$, Soltész, M. ${ }^{2}$, Szabó, Z. ${ }^{1}$ \& Nyéki, J. ${ }^{1}$ \\ ${ }^{1}$ University of Debrecen Centre for Agricultural and Applied Economic Sciences \\ H-4032 Debrecen, 138 Böszörményi Street, Hungary \\ ${ }^{2}$ College of Kecskemét, Faculty of Horticulture H-6000 Kecskemét, 1-3. Erdei Ferenc Square
}

\begin{abstract}
Summary: Today, successful fruit growing depends largely on the security of production. Among the technological elements of a secure growing system, the use of hail protection nets serves special attention. Components of security are the regularity, conspicuous large yields with excellent quality, which determine the prices and profitability as well (Szabó et al., 2010).

In the European Union, most of the apple growing countries produce higher yields by 10-20\% than Hungary. The conditions of better yields are partly due to a more favourable ecological milieu, partly to more developed technologies and serious discipline of the operations. Our own competitiveness could be developed first of all in those moments.

As a consequence of global climatic changes, excesses of weather, i.e. hail-storms became more frequent. Different methods of protection against hail are developed abroad but also in Hungary. The examination of effects of the hail protection nets compared with the check without nets has been the purpose of our experiments. The growing system was the intensive one with high planting densities. Fruits of the two subsequent years have been compared as grown with and without hail protective nets. It turned out that in one season when shoot growth was stimulated, the shadowing effect of the net increased in addition the growth and at the same time braked the differentiation of flower buds, which exerted negative effects on yield of the next year. Let alone this phenomenon, the quality of fruits was not influenced by the hail protection net.
\end{abstract}

Key words: hail protection net, fruit quality, apple varieties

\section{Introduction}

During the last years, excessive weather conditions were often a concern in fruit growing. Varying from year to year, the appearance of hails somewhere in the country occurs with a frequency of 70-140 days per year (Szenteleki et al., 2010). During the summer of 2009 and 2011, hailstorms swept across almost the whole country causing damage in agriculture, whereas in 2010, excessively abundant rains have been observed. The damage caused by hails is a double loss: the fruits are scared directly and the yields of next year impaired by the scares caused on the vegetative parts of the trees (moreover, infections may increase phytosanitary problems), as reported by Gonda (2010).

According to Apáti and Gonda (2010), the loss caused by hail does not end with lack of income from the sales of fruit but there are far reaching consequences too. The major effects are:

- mechanical injuries on the living parts of trees: fruits, leaves, shoots, bark of branches, all of them need expensive phytosanitary care,

- effectiveness of harvesting operations declines because the fruits need an additional reselection either on the tree or at the store,

- the chance of risk increases with the unwanted presence of scared fruits in the containers causing decay in the immediate proximity during the store,

- off years leave the storing capacity unexploited together with the handling personal involved,
- temporary lack of goods may result in loss of markets on the long run.

All those moments suggest the use of hail protection nets as an important alternative of existential survival in fruit growing (Seiler, 2004). In any case, it is an enormous investment with special respect on the economical crisis over the world (Baab et al., 2007). As alternative techniques of protection against hail damage, we may mention the hail protection guns and other communal systems (rockets, soilgenerators and airplanes) outside of our competitiveness. Only the choice of hail protection nets is up to the decisions of the enterprise.

The existence of net means changes in the microclimatic milieu, which needs special adaptations of growing technology (Racskó et al., 2005). From the point of view of light supply, the white nets should be preferred as optimal versus the grey or black colour. Beneath the net, illumination is reduced, therefore, for the sake of yields and quality, choice of adequate apple varieties is an important decision (Ollig, 2004).

Techniques of applying nets over the plantation are continuously improved. The cover should be extended during the most critical period, when also shadow is produced beneficial to avert damages of radiation during noontime (Rakonczás, 2006). Abroad, we may find cases, when damages caused by insects or birds are prevented by hail nets too. 


\section{Materials and methods}

Our observations have been installed at the Experimental Station Pallag of the Debrecen University, in 2010-2011. Trees were grafted on M9 stocks as 'Gala Galaxy' and 'Gala Must' varieties planted in the spring of 2007. Planting design was $4 \mathrm{mx} 1 \mathrm{~m}$, and they were trained to form slender spindle crowns. The soil was sandy with low (1\%) humus content. Our plantation was covered by black hail net. Near by, the check plants stood without net cover.

The effect of the hail net cover has been observed on the following properties:

Changes in cross section area of the trunk (TKM) in $\mathrm{cm}^{2}$.

Specific number of flowers (flowers/TKM $\mathrm{cm}^{2}$ )

Specific number of fruits set (fruit/TKM $\mathrm{cm}^{2}$ )

Yield ( $\mathrm{kg} /$ tree)

Measure of fruit size (mm)

Mass of fruits (g)

Flesh firmness

Soluble solids content $(\mathrm{g} / \mathrm{l})$

Fructose (g/l)

Citric acid (g/l).

In the first year of the experiment, 2010, precipitation reached $1000 \mathrm{~mm}$, whereas in 2011, July 11, a hailstorm roamed over the plantation with $53 \mathrm{~mm}$ precipitation. Thus the opportunity to measure the damage of uncovered trees was given as cracking, suberification (rusting) and rotting.

Measures are performed by a digital slide-gauge of the Kinex type, kalimeter, digital scales (Radwag WPS 210/C/2, Random, Poland), digital refractometer (Atago) and penetrometer. The starch test needed potassium iodide.

\section{Results}

In Figure 1, the changes in the trunk cross section area of the two apple varieties are presented.

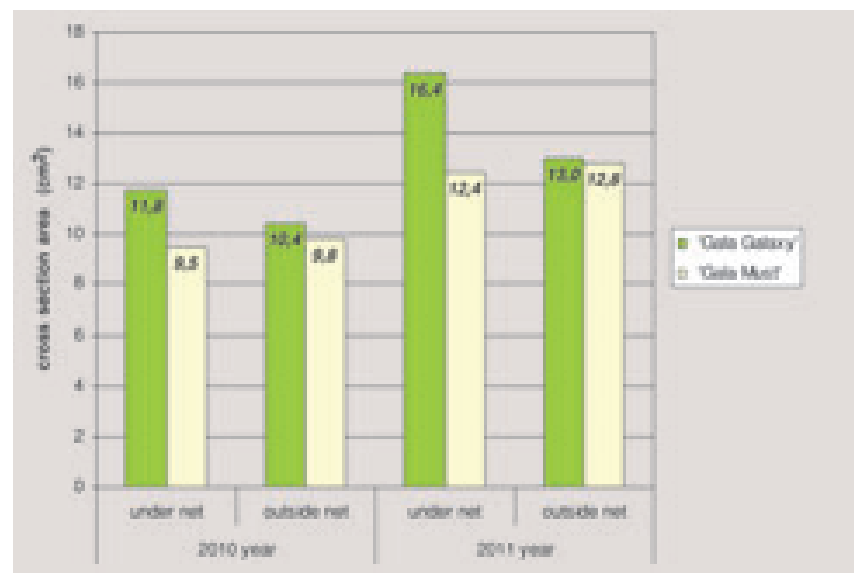

Figure 1. Changes of cross section area in the trunks of trees under and outside the hail protection nets (Debrecen - Pallag, 2010-2011)

Our data show that trunks of trees under the hail net grew faster than outside. We have to remark that the increment of cross section area is influenced by the yields of the former and present year. In Figure 2, the specific number of flowers are shown also under and outside of the hail net.

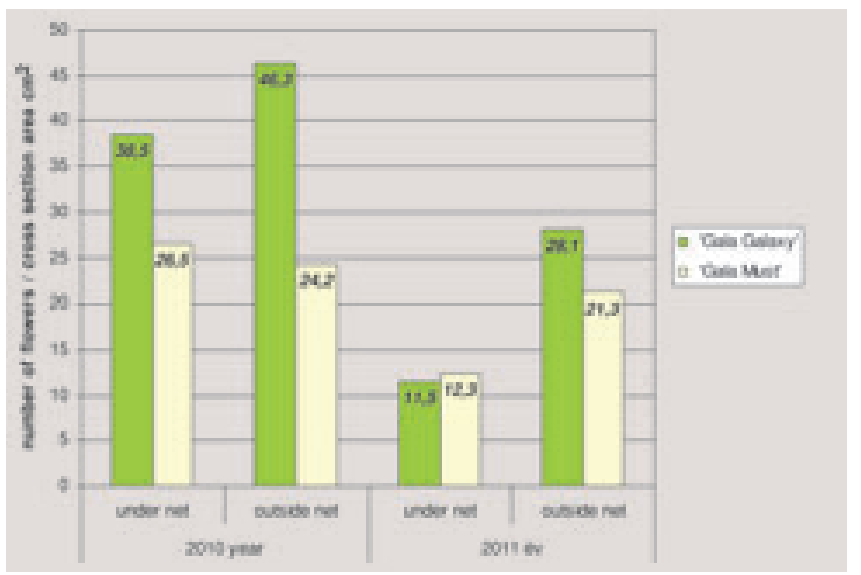

Figure 2. Specific number of flowers under and outside of the hail nets (Debrecen - Pallag, 2010-2011)

In 2010, the variety Gala Galaxy had less flowers under the net, whereas the other variety, Gala Must, produced nearly equal values. In 2011, flower number were lower under the hail net than outside in both varieties.

As mentioned, in 2010, there was an enormous large quantity of precipitation, which stimulated the vegetative growth. Many shoots are initiated mainly under the hail net, and the growing period of shoots was prolonged. Shoots finished their growth by terminal buds later; consequently, the time left for flower bud initiation was markedly shorter. Both varieties produced a lower number of flowers in 2011, as a reaction to the copious water supply and less sunshine in 2010.

The specific number of fruits is found on Figure 3.

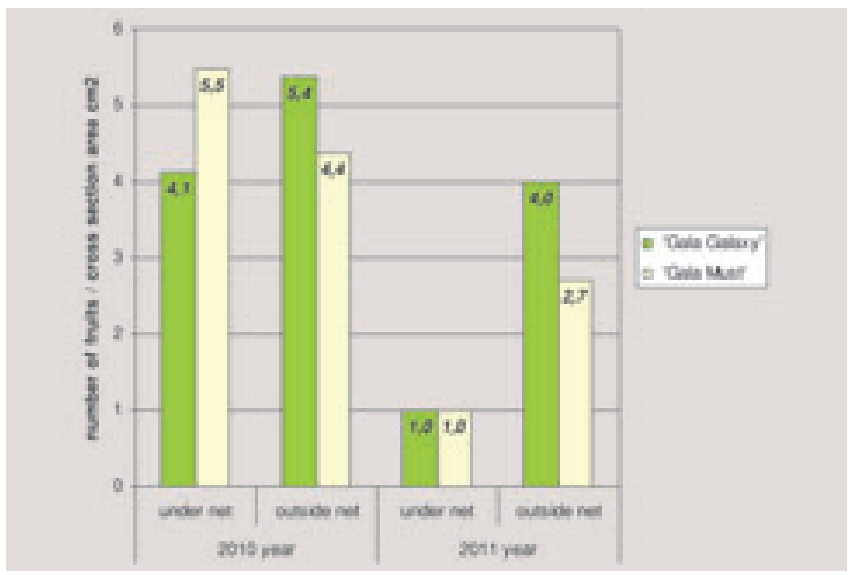

Figure 3. Specific number of fruits of apple varieties under and outside the hail nets in the successive years (Debrecen-Pallag, 2010-2011)

Gala Galaxy produced in both years more fruit outside the hail net than under the net. In Gala Must, the same tendency was observed in 2011 only. In the same year, the low number of flowers explains the low number of fruits too.

In Figure 4 the number of fruits per tree are presented. 


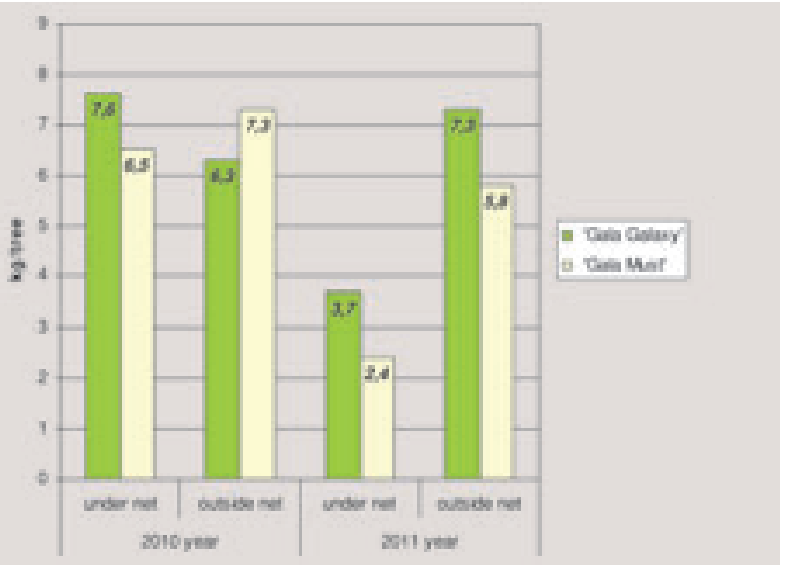

Figure 4. Fruit load of trees under the hail net and outside of it. (DebrecenPallag, 2010-2011)

In 2010, the fruit load of Gala Galaxy was higher under the hail net whereas Gala Must produced more outside the net.

The indices of fruit quality are presented in Table 1.

Table 1. Parameters of fruit quality under the hail net and outside of it (Debrecen-Pallag, 2010-2011)

\begin{tabular}{|c|c|c|c|c|}
\hline $\begin{array}{c}\text { Parameters } \\
\text { observed }\end{array}$ & $\begin{array}{l}\text { The year of } \\
\text { observation }\end{array}$ & Apple varieties & \begin{tabular}{|c|} 
'Gala \\
Galaxy' \\
\end{tabular} & $\begin{array}{l}\text { 'Gala } \\
\text { Must' }\end{array}$ \\
\hline \multirow{4}{*}{ Fruit mass (g) } & \multirow{2}{*}{2010} & below the net & 194.7 & 185.2 \\
\hline & & outside the net & 190.9 & 193.6 \\
\hline & \multirow{2}{*}{2011} & below the net & 202.9 & 185.2 \\
\hline & & outside the net & 207.3 & 192.6 \\
\hline \multirow{4}{*}{$\begin{array}{l}\text { Fruit diameter } \\
(\mathrm{mm})\end{array}$} & \multirow{2}{*}{2010} & below the net & 74.9 & 73.9 \\
\hline & & outside the net & 74.7 & 74.7 \\
\hline & \multirow{2}{*}{2011} & below the net & 75.4 & 70.3 \\
\hline & & outside the net & 77.3 & 75.2 \\
\hline \multirow{4}{*}{ Flesh firmness } & \multirow{2}{*}{2010} & below the net & 7.6 & 7.6 \\
\hline & & outside the net & 7.6 & 7.6 \\
\hline & \multirow{2}{*}{2011} & below the net & 8.8 & 9 \\
\hline & & outside the net & 8.8 & 9.2 \\
\hline \multirow{4}{*}{ Citric acid (g/l) } & \multirow{2}{*}{2010} & below the net & 1.4 & 1.5 \\
\hline & & outside the net & 1.6 & 1.5 \\
\hline & \multirow{2}{*}{2011} & below the net & 2 & 2.3 \\
\hline & & outside the net & 1.7 & 2.2 \\
\hline \multirow{4}{*}{ Fructose (g/l) } & \multirow{2}{*}{2010} & below the net & 1.5 & 1.5 \\
\hline & & outside the net & 1.5 & 1.5 \\
\hline & \multirow{2}{*}{2011} & below the net & 1.6 & 1.9 \\
\hline & & outside the net & 1.3 & 1.8 \\
\hline \multirow{4}{*}{ Soluble solids (g/l) } & \multirow{2}{*}{2010} & below the net & 11.9 & 12.1 \\
\hline & & outside the net & 12.6 & 12.4 \\
\hline & \multirow{2}{*}{2011} & below the net & 11.5 & 11.9 \\
\hline & & outside the net & 9.5 & 13.1 \\
\hline
\end{tabular}

In 2010, 'Gala Must' yielded equally heavy fruits under as well as outside the hail net. Size and weight of fruit depends on total fruit yield. Where more fruit/tree was grown, the mass of individual fruits dwindles. Outside the net, more fruits with lower weights appeared. So, in 2010, 'Gala Must' grew larger fruits outside the net but not too much. More differences were in 'Gala Galaxy', the fruits under the net grew larger.

In flesh firmness, no differences could be detected between the two growing conditions. It's worth while to mention that the larger fruits under the net were equal in flesh firmness with those grown outside of the net. There, we may surmise that the hail net could be beneficial for flesh firmness.

The effect of the hail storm on the quality of fruits in 2011

The hail of July 2011 hurt fruits outside the hail net only, where the damage was outstanding as shown in Figure 5.

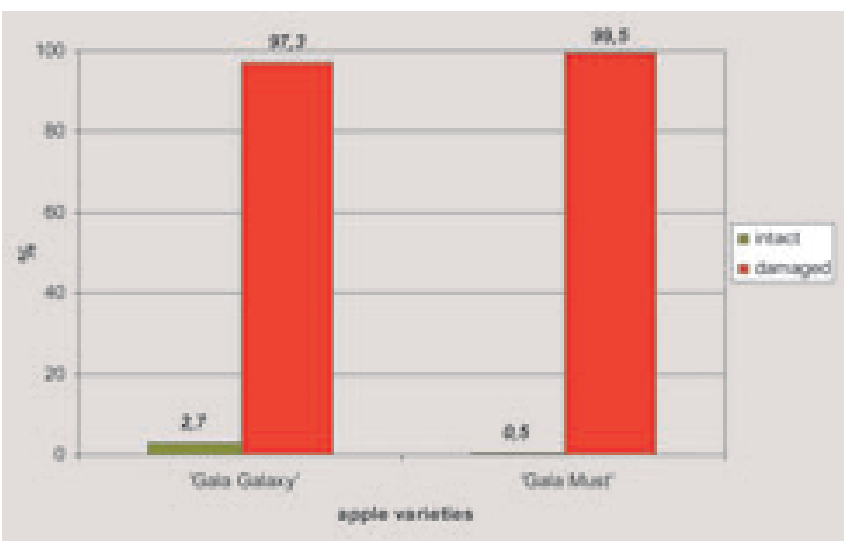

Figure 5. Damage caused by hail outside the hail protection net (DebrecenPallag, 2011)

The hail damage was extraordinary, as less than $3 \%$ of fruits were unimpaired outside the net. Variety 'Gala Galaxy' was most hurt. The decline of quality caused also increased expenses because the selection of fruits either during the harvest or later when preparation for the market or store were actual. Moreover, the risk of decay threatens during the storing period.

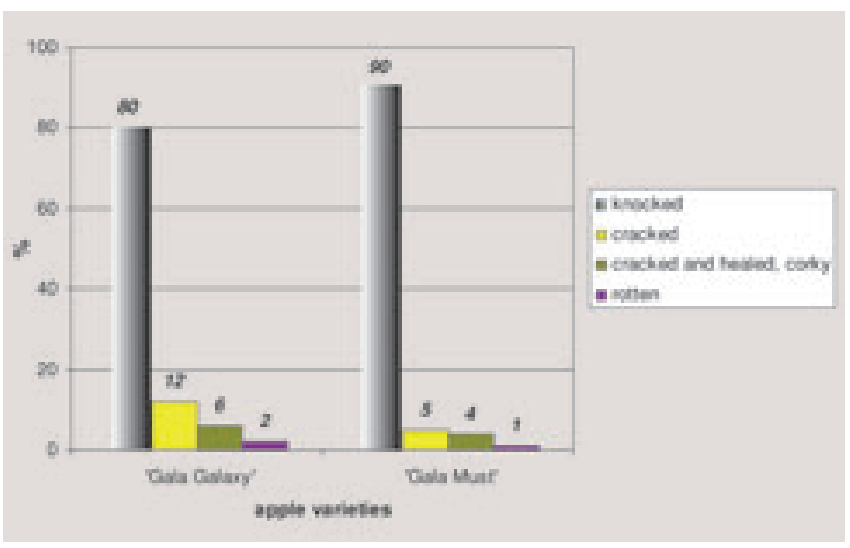

Figure 6. Typology of the damage caused by hail on apple fruits (DebrecenPallag, 2011) 
The scares caused by hail are distributed into four categories (Figure 6). 1: the knock on the surface of the fruit by a falling grain without breaking the epidermis. 2: cracking is the next category, when the peel of the fruit is interrupted, and decay is risked. 3: crack, which healed and became corky, which supposes that the scare was relatively little. 4 : rotten, when the decay started on the tree already.

The most frequent category is the number 1 , i.e. knock, and then follow the others with diminishing abundance and increasing severity. The danger of infection supposes a scare. Most of the damages mean total loss of the grower with consequences reaching through the next years. Heavy damage may endanger the fate of the enterprise. 'Gala Must' was less impaired in our case.

The hail also scares the tree, which needs time for regeneration and as a consequence, lower yields are expected in the next years.

\section{Conclusions and suggestions}

According to our opinion, the use of hail protection nets is recommended by all means, even on sites where hails are not registered regularly.

The clear superiority in flowering, specific and absolute yields of the trees outside the hail protection net is due to the extreme vegetative performance of the trees during the previous year. In the previous year, 2010, the copious rains caused the extraordinary, about $30 \%$ more vegetative output in shoots, which delayed the differentiation of flower buds as an immediate cause of lower bloom and yield. Outside the hail net, the shoots developed terminal buds earlier (by 10-14 days), which resulted in more flowers next year. The interrelation between size of fruits and yields per tree was obvious, but the rest of parameters are less evident or cannot be related to growth and yields.

From the point of view of quality, the conclusion is ambiguous or even contrasting. According to results, the hail protection net did not improve the quality of fruit.

Regarding the income due to sales, the hail nets may promise $100 \%$ protection when hails occurred.

Our experiences conclude to recommend the use of nets in modern (intensive) plantations. As most advantageous, the nets should be erected just with the installation of the plantation together with the supporting structure, but the construction in an existing plantation is more complicated. In spite of the prosperous indications and the subsidies promised, the plantations do not invest but at low frequencies in hail protection nets in Hungary.

Acknowledgement: This work was supported by NFÜ TECH- 08- A4/2-2008-0138,

TECH-08-A3/2- 2008-0373 and TÁMOP -4.2.2/B-10/12010-0024 grants.

\section{References}

Apáti, F. (2010): A jégeső elleni védekezés lehetőségei és gazdasági összefüggései a gyümölcstermesztésben. [In: Soltész, M., Nyéki, J., Szabó, Z. (2010): A magyarországi gyümölcstermesztés biztonsága.] Debreceni Egyetem. Kecskeméti Főiskola.

Apáti, F. (2010): A jégesők okozta károk és az ellenük való védekezés üzemi lehetőségei. Agrofórum. 21. 7: 90 p.

Baab, G., Kunz, A. \& Blanke, M. (2007): Einfluss von Hagelnetzen auf Mikriklima, Wuchsverhalten, Ertrag und Qualitat. Obstbau. 4: 186 p.

Baab, G., Kunz, A. Steinbauer, L. (2007): Hagelnetze. Dienstleistungszentrum, Rheinpfalz, Uni Bonn. 20-21, 24 p.

Gonda, I. (2010): Eddigi tapasztalatok a gyümölcsösöket ért jégkárról és a védekezési lehetőségekről. [In: Soltész, M., Nyéki, J., Szabó, Z. (2010): A magyarországi gyümölcstermesztés biztonsága.]

Lakatos, L., Gonda, I., Kocsisné Molnár, G., Soltész, M., ZhongFu, S., Szabó, Z., Nyéki, J. (2011): Jégvédő háló alatti mikroklíma almaültetvényben. „KLÍMA-21” Füzetek. 64: 123 p.

Ollig, W. (2004): Einfluss von Hagelnetzen auf Ausfarbung und Sonnenbrand. Obstbau. 6: 310-311.

Racskó, J., Nyéki, J., Soltész, M., Lakatos, L., Harsányi, G. \& Szabó, Z. (2005): Jégvédő hálók alkalmazása az almatermelésben. „AGRO-21” Füzetek. 45: 112 p.

Rakonczás, N. (2006): Az alma minőség- meghatározásáról. Zöldség- és Gyümölcs Piac. 10. (11-12): 12 p.

Seiler, W. (2004): Hagelnetz-Konstruktionen-Folienüberdachungen. Obstbau. 8: 423 p.

Szabó, Z., Nyéki, J. \& Soltész, M. (2010): A termésbiztonság és minőség tényezői a bio- és integrált gyümölcstermesztésben. [In: Soltész, M., Nyéki, J., Szabó, Z. (2010): A magyarországi gyümölcstermesztés biztonsága.] $15 \mathrm{p}$.

Szenteleki, K., Gaál, M., Mézes, Z. \& Lakatos, L. (2010): Időjárási anomáliák Nyugat- Magyarországon. [In: Soltész, M., Nyéki, J., Szabó, Z. (2010): A magyarországi gyümölcstermesztés biztonsága.] 25, 34 p. 